\title{
Rhizogenesis Analysis of Some Olive Accessions
}

\author{
Adriatik Çakalli $^{1 *}$, Hairi Ismaili ${ }^{1}$, Endrit Kullaj ${ }^{2}$ and Ervin Shishmani ${ }^{3}$ \\ ${ }^{1}$ Center for Genetic Resources, Agriculture University of Tirana, Albania \\ ${ }^{2}$ Department of Horticulture and Landscape Architecture, Agriculture University of \\ Tirana, Albania \\ ${ }^{3}$ Food Science and Biotechnology Department, Agriculture University of Tirana, Albania \\ *Corresponding author
}

\begin{tabular}{|c|c|}
\hline & A B S T R A C T \\
\hline $\begin{array}{l}\text { Ke y w o r d s } \\
\text { IBA, Olive, Rhizogenesis, } \\
\text { Callus genesis, Sprig, } \\
\text { Cuttings }\end{array}$ & \multirow{3}{*}{$\begin{array}{l}\text { This experiment which was carried out at the experimental station in Peza Vogël (Tirana } \\
\text { district) presents some physiological aspects of rhizogenesis in the olive propagation with } \\
\text { green cuttings. The method has considered } 13 \text { different olive accessions originated from } \\
\text { the genetic and phytosanitary selection process. Four treatments with indol-3 butyric acid } \\
\text { and one control were applied under mist propagation method. We used the Van der } \\
\text { Waerden Test to statistically analyze the differences in rhizogenic performance between } \\
\text { propagated olive accessions with different concentrations of indol-3 butyric acid. In } \\
\text { general, all accessions had good rooting under intensive vegetative growth with } \\
\text { concentration levels of } 3000 \text { ppm. We concluded that concentrations with values higher or } \\
\text { lower than } 3000 \mathrm{ppm} \text { have given reduced rooting rates because this period corresponds } \\
\text { with a high vegetation flux of endogenous auxins. }\end{array}$} \\
\hline Article Info & \\
\hline $\begin{array}{l}\text { Accepted: } \\
\text { 20 September } 2018 \\
\text { Available Online: } \\
10 \text { October } 2018\end{array}$ & \\
\hline
\end{tabular}

\section{Introduction}

Many researchers have been realized that the efficacy of propagation is influenced by different factors such as endogenous hormonal stimulants (Florino, 1980; Daoud, et al., 1989). The use of auxins treatments, mainly Indole-3 Butyric Acid, allowed to standardize the technique and identify alternative methods (Fabbri, 1980), with relatively constant results achieved only if conditions remain unchanged pick Caballero, (1993), if one takes proper account of the phonological phases of the material subjected to rooting Loreti, et al., (1964), age and condition of the mother plants Bartolini et al., (1989). All factors that play a role too often not adequately assessed by the operators. The use of hormones is studied by many authors, as Hartmann, et al., (1952), Rodriguez, et al., (2008); Fernandez-Serrano, et al., (2002) etc, where they provide information about the effects of rooting of olive vegetative cuttings, with different ways.

But the, application of the plant hormone has many aspects for solution, for example; the chemical nature, the dose concentration, retention time in solution, combination with other substances, treatment conditions, etc. The individual genetic ability is another aspect important, especially for varieties resulting difficult (Ismaili et al., 2014). 
In this research, the effects of different IBA doses have been tested in relation to 13 olive selections with superior genetic potential that are in the populations of five autochthonous varieties.

\section{Materials and Methods}

Plant material consisted in 13 olive selected accessions, namely: KP1, KP2, KP3, KO12, KJ20, BT200, KB222, HH10, KKR3, KB661, KB226, KB224, HH4. The age of mother trees in situ was more than 1500 years old. Shoots were collected in May and green cuttings 8 $12 \mathrm{~cm}$ were prepared, with two pairs of leaves in the apical part. The stimulant used was Indole-3 butyric acid $\left(\mathrm{C}_{13} \mathrm{H}_{12} \mathrm{NO}_{2}\right)$ hydroalcoholic solution. Factor levels were: (i) Control; (ii) IBA 1000 ppm (iii) IBA 3000 ppm, (iv) IBA 5000 ppm. A random block design was used with 100 cuttings per treatment, with 4 replicates. The duration of the rooting stimulation with hormone was 4 second for each treatment, except Control which was treated with water. Te hydroalcoholic ratio was $(3: 1)$ and alcohol $96^{\circ}$.

The cuttings were planted in a misting bench with perlite as a substrate. The air temperature was kept at $18^{\circ} \mathrm{C}\left( \pm 1^{0} \mathrm{C}\right)$, while one the substrate $24^{0} \mathrm{C}\left( \pm 1^{0} \mathrm{C}\right)$, which was achieved through a heating source with hot water circulation using pumps, thermostats and other control equipment.

Misting was made for 5 seconds in each 13 $\mathrm{Wh} / \mathrm{m}^{2}$, in function of the active solar radiation, auto-compensative through a solar integrator SI-20.

The indices used for the rooting process were: (i) rooting percentage, (ii) total callus percentage, (iii) quality of rooting, number of secondary roots and length of primary roots. The number of fallen leaves, number of cutting with callus.
For the statistical analysis, the research variables were modelled and the descriptive analysis for variance, standard deviation, test variability, correlations was carried out using Statgraphix software (2012).

\section{Results and Discussion}

In Table 1, we have presented the average rooting percentages, the level of callus formation, $\mathrm{R} / \mathrm{C}$ ratio and defoliation ratio in percentage. These are the main performance indices of the bio-physiological process. From one side, using the control, we found that the endogenous capacity is a genetic characteristic, as it is extraordinary variable among accessions. In this case, the accessions have an average rooting lower than "Control" treatment, $12.4 \%$ and a very high differences between them because, in general, rooting percentage has a large amplitude $\mathrm{R}=27.2$ and $\mathrm{CV}=66.9 \%$. Rooting of each accession was characterised by a strong correlation between callusing, $\mathrm{R} / \mathrm{C}$ ratio and defoliation percentage. As it can be seen, the natural ability is a genetic trait and cannot be modified (Ismaili, et al., 2014).

From the other side, after the application of phytoregulator to stimulate rhizogenesis, their concentrations have increased the rooting efficacy expressed as a percentage of rooting and differentiated callus. A strong correlation was found between the physiological research indices. Relative to control, the percentage of rooting has been higher up to a concentration of $3000 \mathrm{ppm}$ and further increase did not correlated with increased rooting percentage. Under such conditions, the treatments based on rooting percentages were ranked as follows: IBA3000> IBA5000> IBA1000> Control. Their respective percentages were: $63.3 \%>43.5 \%>31.4 \%>12.4 \%$.

Changes in all physiological indices are characteristic in all accessions and have the 
same presence and ratio between them. R/C ratio is an important rhizogenic indicator because it expresses the quality and propensity for rooting. The value of $\mathrm{R} / \mathrm{C}$ ratio was strongly correlated to the rooting percentage. The highest value of this ratio was found at IBA 3000ppm treatment, while its values are positively proportional expressing a strong correlation $\mathrm{r}=0.89$.

Analysis of variance have shown that average values rooting percentages, callusing and defoliation percentages were statistically different in each treatment, for $\mathrm{q}^{*}$ level, referring to LSD. The average of each treatment was characterized for the standard deviation and is characteristic for the variety. This experiment has confirmed that treatment with IBA 3000 ppm was better compared to other treatments, especially compared to IBA $5000 \mathrm{ppm}$. The decrease of rooting percentage under $5000 \mathrm{ppm}$ concentration can be explained with the level of toxicity caused by this treatment is due to the high concentration of endogenous auxins at this development stage because in May there is already a high vegetative flux and the level of endogenous natural auxins is the highest compared to other seasons.

Beside the analysis of averages of each treatment in correlation with the averages of each accession, we found that in all cases, the latest have typical rooting values and very different in terms of averages, frequencies, amplitudes and coefficient of variation (see Table 1).

Accession KP1 and KP2 had the highest percentage of rooting of $89.5 \%$ and $90.6 \%$ respectively, by showing in each treatment a predominance respective to other accessions. Accessions with a low rooting ability were HH4 and HH10 (see Table 1, Figure 1 and 2). Analysis of performance for rooting percentage has concluded the following sequence of treatments: IBA 3000> IBA 5000> IBA 1000> Control but also the level of variation expressed with amplitude $\mathrm{R}=36$. In this case, we found that varieties have a different rooting ability and are ranked in the following sequence: KP3> KJ20> KP2> KO12> KP1> KKR3> BT200> KB224> KB226> KB222> KB661> HH10> HH4 (see Figure 1 and 2).

We found strong correlations not only between accessions and IBA concentration but also between accessions, callus, $\mathrm{R} / \mathrm{C}$ ratio and the level of defoliation in green cuttings (see Figure 1 and 2).

The level of natural rhizogenesis shows a considerable variation and is affected by the genetic characteristics of olive genotypes. These results were found also in research conducted by other authors (Ismaili, 2017; Cabalero, 1989).

Rhizogenesis of each responsible genotype had specific ratios with callus formation process and we found to be the responsible genotype for this index. Our data are similar to the results of many authors, especially in relation to the rhizogenic phenomenon.

In all concentrations of IBA, R/C have a normal index $0,39-0,70$, while there have been reports in literature of negative control $(0,26)$ in the case where the stimulation was not used. Rooting ability of accessions is different and correlated with IBA concentration applied.

We found a wide amplitude of frequencies for rooting in each treatment and in correlation with each accession. Accessions $\mathrm{HH}$ and $\mathrm{KB}$ did not have a positive response with none of the IBA concentrations. Therefore, we it can be said that the variety (genetic traits) were important factors in the process of callusing and rooting (Fig. 3). 
Table.1 The average data for rooting $\%$, call genesis $\%$, ratio $\mathrm{R} / \mathrm{C}$ and defoliation $\%, 13$ varieties of olive and analysis of variable density; the average, Stand Dev and CV

\begin{tabular}{|l|l|l|l|l|l|l|l|l|l|l|l|l|l|l|l|l|}
\hline $\begin{array}{l}\text { Treatment } \\
\text { Variety }\end{array}$ & R & C & R/C & D & R & C & R/C & D & R & C & R/C & D & R & C & R/C & D \\
\hline KP1 & 21.3 & 46.0 & 0.46 & 77 & 42.4 & 86.2 & 0.49 & 36 & 89.5 & 92.8 & 0.96 & 8 & 55.5 & 93.3 & 0.59 & 32 \\
\hline KP2 & 27.2 & 48.0 & 0.56 & 69 & 37.4 & 85.0 & 0.44 & 47 & 90.6 & 96.3 & 0.93 & 11 & 66.3 & 95.4 & 0.69 & 34 \\
\hline KP3 & 19.8 & 43.5 & 0.45 & 70 & 63.2 & 89.8 & 0.70 & 33 & 84.6 & 94.4 & 0.89 & 10 & 68.0 & 91.0 & 0.74 & 30 \\
\hline K012 & 22.4 & 40.4 & 0.55 & 55 & 53.8 & 88.0 & 0.61 & 40 & 87.2 & 92.8 & 0.94 & 0 & 59.6 & 96.3 & 0.61 & 38 \\
\hline KJ20 & 18.8 & 48.7 & 0.38 & 50 & 75.5 & 86.8 & 0.86 & 29 & 80.7 & 93.6 & 0.86 & 4 & 62.5 & 92.5 & 0.67 & 25 \\
\hline BT200 & 17.6 & 56.2 & 0.31 & 29 & 13.3 & 79.5 & 0.16 & 53 & 77.8 & 87.4 & 0.88 & 0 & 54.4 & 88.3 & 0.61 & 27 \\
\hline KB222 & 4.3 & 49.3 & 0.08 & 85 & 15.0 & 66.6 & 0.22 & 56 & 51.6 & 85.3 & 0.6 & 34 & 19.6 & 85.8 & 0.22 & 30 \\
\hline HH10 & 1.5 & 17.7 & 0.08 & 45 & 11.6 & 71.5 & 0.16 & 77 & 23.5 & 78.8 & 0.29 & 22 & 13.6 & 88.4 & 0.14 & 35 \\
\hline KKR3 & 10.3 & 47.3 & 0.21 & 52 & 49.4 & 69.4 & 0.71 & 34 & 62.3 & 80 & 0.77 & 10 & 48.3 & 92.4 & 0.52 & 18 \\
\hline KB661 & 3.5 & 36.6 & 0.09 & 80 & 13.8 & 55.3 & 0.24 & 72 & 49.5 & 83.6 & 0.59 & 26 & 28.2 & 83.6 & 0.33 & 28 \\
\hline KB226 & 4.6 & 32.0 & 0.14 & 77 & 12.9 & 58.6 & 0.22 & 70 & 51.5 & 88.5 & 0.58 & 20 & 31.6 & 90.4 & 0.34 & 45 \\
\hline KB224 & 5.3 & 33.4 & 0.15 & 83 & 10.5 & 60.4 & 0.17 & 67 & 55.2 & 90.4 & 0.61 & 25 & 39.6 & 92.2 & 0.42 & 40 \\
\hline HH4 & 0.0 & 18.0 & 0.0 & 41 & 10.3 & 65.5 & 0.16 & 75 & 19.4 & 72.3 & 0.26 & 18 & 18.5 & 79.6 & 0.22 & 26 \\
\hline Mean & 12.4 & 39.7 & 0.26 & 62 & 31.4 & 74.0 & 0.39 & 53 & 63.3 & 87.4 & 0.70 & 14 & 43.5 & 89.9 & 0.46 & 31 \\
\hline Std Dev & 8.3 & 11.8 & 0.19 & 18 & 23.2 & 12.3 & 0.25 & 17 & 24.1 & 7.1 & 0.23 & 10 & 19.3 & 4.74 & 0.20 & 7 \\
\hline CV & 66.9 & 28.2 & 73.0 & 29 & 74.1 & 16.2 & 64.1 & 32 & 38.1 & 8.1 & 32.8 & 71 & 44.2 & 5.2 & 43.4 & 22 \\
\hline
\end{tabular}

$R$-Cuttings with root, $C$-total Callus, $R / C$ - Report to root cuttings versus cuttings Callus, $D$ - Defoliation \%.

Fig.1 Ratio R / C is resulted for 13 olive accessions, in different concentrations of IBAs and Control; Fig.2 Graphic representation of rhizogenesis of olive accessions in relation with three different concentrations of IBAs and Control
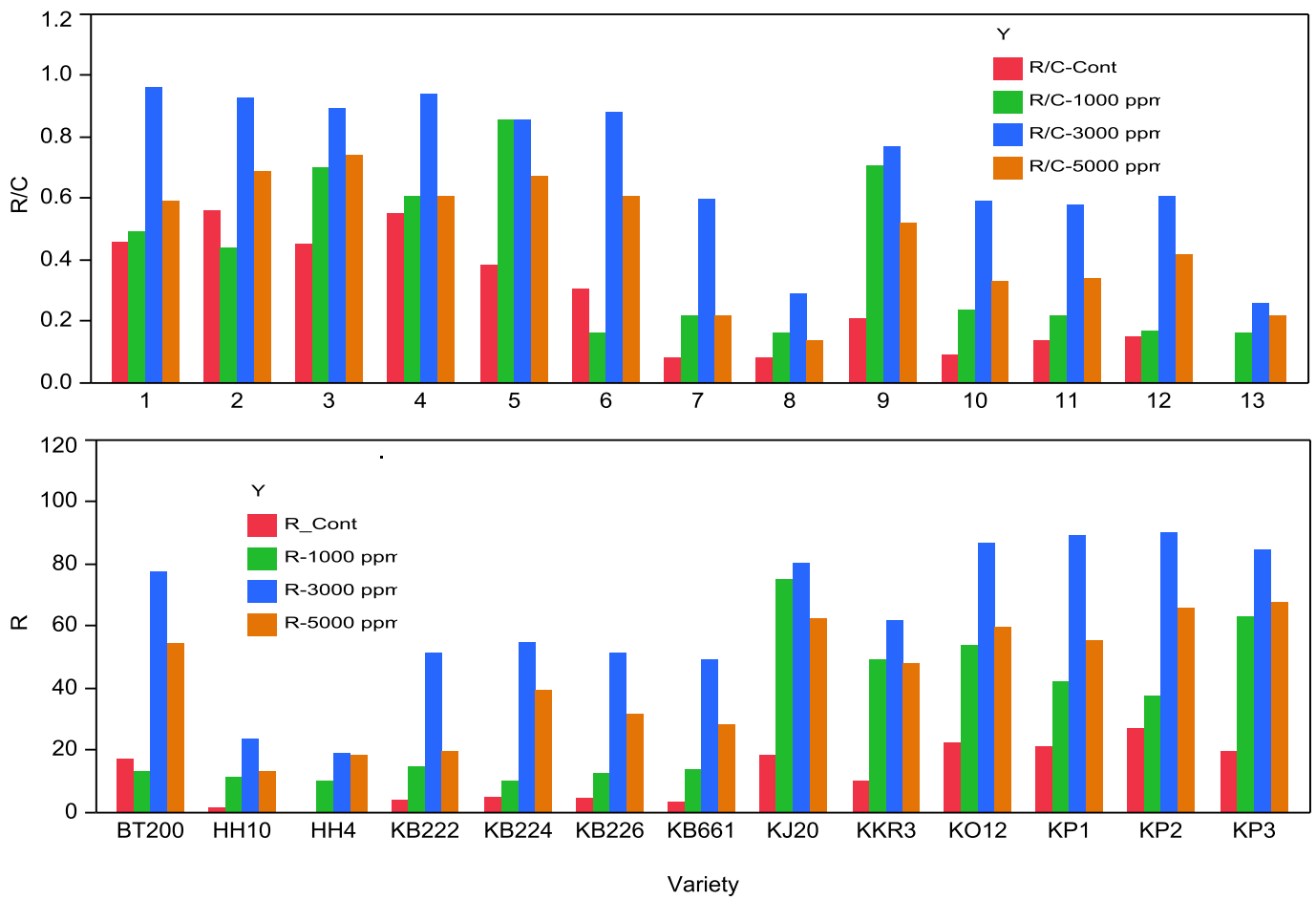
Fig.3 Dendrograme onevay analysis of rooting by treatment for testing the variability analyzed all pairs, Prob $>\mathrm{F}<.0001 *$

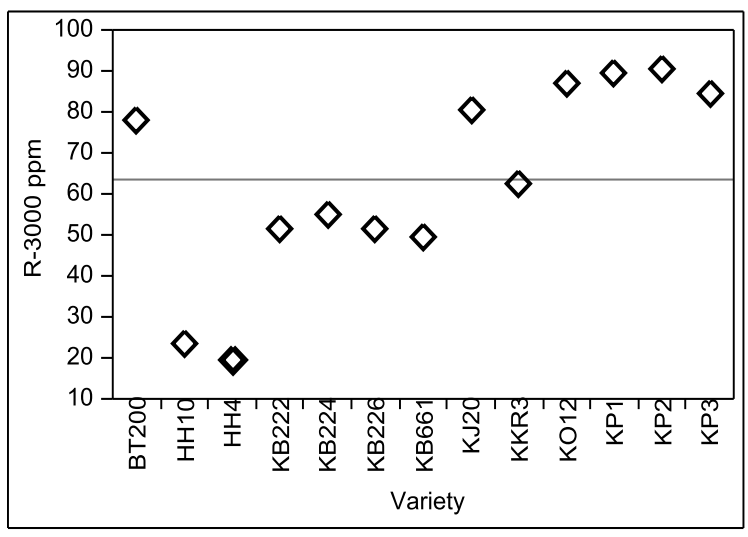

Leaves played an important role for photosynthesis and nutrition with carbohydrates and stimulation of first roots. Apical leaves have play and important role in photosynthesis but, when they fall, callus tissues and green shoots are dead.

Leave fall varied from $14 \%$ to $62 \%$ (Table 1). The lowest percentage of leaves felt was found in factor level IBA 3000ppm with $14 \%$. Varieties with more resistant leaves were KP3, KKR and BT. The biggest leaf drop was in control with $62 \%$. Rhizogenesis was closely related to IBA doses and the individual characteristics of the genotype. When the R/C ratio was close to unity (1), it served as an index of good rhizogenic mass and these concepts were also found in research carried out by many Spanish, Italian and Albanian authors (Caballero et al., 1997; Bartolini et al., 1988; Ismaili et al., 2014).

The callus tissue was regenerated at the base or in all the internode segment of the base, two weeks later until the full root induction for 35 days. The callus formed by the reproduction of parenchyma cells of the cortex and phloem, inside and outside the sclerenchymatic ring.

In presence of IBA, the genotypes strengthened the effect of rhizogenesis in rapid proliferation of cells and with a large mass of callus. We can

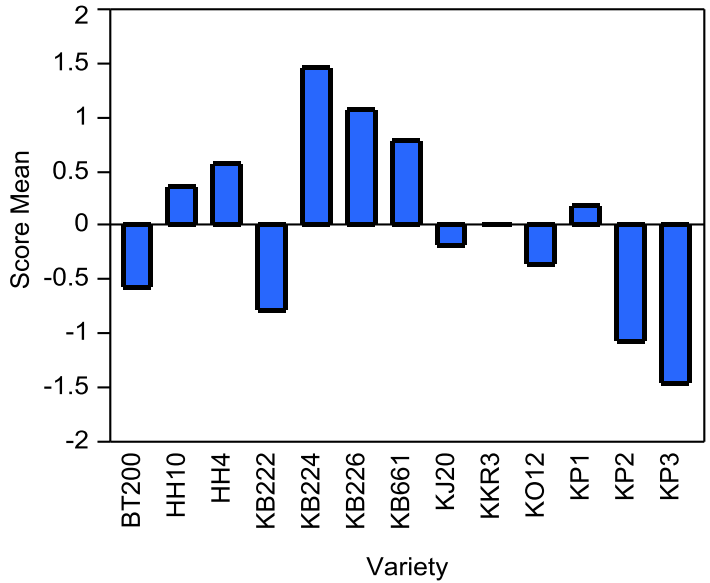

state that IBA $3000 \mathrm{ppm}$ has given favourable results for rhizogenesis because in all trials has considerably contributed to the formation of callus tissue. Thus, the phenomenon of rhizogeneis was closely related to IBA and the individual characteristics of the genotype.

The best results in terms of rooting percentage during the vegetative growth are not the highest concentrations but, in general, the medium ones. There are cases where there was no root differentiation, i.e. accession $\mathrm{HH}$, and this is a genetic characteristics that is caused by the lack of enzyme stimulation synthetized by auxin complexes assimilated by the phloem.

On the same basis, there are some accessions where the mitotic roots are developed along the entire length of internode that corresponds to the tissues from which they are formed, e.g. $\mathrm{KP} 3, \mathrm{KJ} 20$ etc and these phenomena are found by other authors like (Ismaili et al., 2010; Caballero et al., 1997; Fiorino et al., 1980). etc. In general, rooting of green cuttings is a physiological process strongly related to the genetic traits, vegetative growth indices and concentration of exogenous synthetic hormones. Olive accessions did not have the same rhizogenic performance in correlation to the hormone doses because they had a high amplitude for each IBA dose, which has differently stimulated this process. 
The existence of leaves until the end of this process was better when they were treated with IBA $3000 \mathrm{ppm}$ than $5000 \mathrm{ppm}$, while under such circumstances there is a higher percentage of rooting. This underlines the importance of leaf presence during the transition of physiological processes of callusing and rooting.

\section{References}

Bartolini, G., Fabbri, A., Tattini, A. 1988. Phenol acids and rhizogenesis in cuttings of "Frangivento" olive. Olea.19 p.73- 77.

Berthon, JY. Battraw, M.J., Gaspar, J., Boyer, N. 1993. Early test using phenolic compounds and peroxides activity to improve in vitro rooting of Sequoiadendron gigantean. Societe Bot. 24:7- 13.

Caballero, JM., Rallo, L., 1977. Duration del period de enraizamento del olivo (Olea europea) por estaquillado semilenoso bajo nebulizacion. Olea. 2:29- 39.

Cantini, C., Cimato, A., Sani, G, 1999. Morphological evaluation of olive germplasm present in Tuscany region. Euphytica 109 (3): 173-181

Daoud, A., Aghaj, T., Abu-Lebda, K. H., Alkhariat, M. S. 1989. Incidence de l'AIB sur l'enracinement des boutures feuillées d'olivier. Olivae, (27) 28-30.

Fabbri, A. 1980. Influenza di alcuni caratteri anatomic sulla radicazione di tale di olive cv "Frangivento". Riv Ortoflorofrutt Ital. 64:325- 335.

Fernandez-Serrano, JM., Serrano, M.C., Amaral, E. 2002. Effect of different hormone treatments on rooting of Olea europaea cv Galega vulgar cuttings. Acta Hort. 586:875- 877.
Fiorino P. \& Cimato A, 1980: Stato attuale delle conoszenze sulla moltiplicazione dell'olivo con la tecnica della nebulizzazione. L'informatore agrario, $38 ; 12-30$.

Hartmann, HT. Loreti, F. 1965. Seasonal variation in rooting leafy olive cuttings under mist. Proc Am Soc Hort. Sci. 87:194- 198.

Hartmann, T. 1952. Further Studies on the propagation of the olive by cuttings. Proc. Amer. Soc. Hort. Sci., (59) 155-160.

Ismaili, H. (2010). The influence of indole-3 butyric acid (IBA) in different concentrations in the percentage of olive cv. Rooting in Albania. Alba-Shkenca, ALPA 2010 (5) 321.

Ismaili, H., Cakalli, A. 2014. Call genesis and the influence of IBA on rhizogenesis of olive green parts. Albanian J. Agric. Sci. Volume 13, Special issue (2014) pp. 75 79

Ismaili, H., Llanaj, L.1., Prifti, R. 2014: Propagation of Albanian olive varieties. Journal of Endocytobiosis and Cell Research V. 25 p. 47-52

Jmp, SAS (2008) Statistical Analysis with Software. Version 6. Institute Inc. Cary.SAS Users Guide.

Loreti, F., Hartmann, HT., 1964. Propagation of olive trees by rooting leafy cuttings under mist. Proc Am Soc Hort Sci. 85:257- 264.

Rodriguez, F., Guzman, JL., Berenguel, M., Arahal, MR. 2008. Adaptive hierarchical control of greenhouse crop production. Int J Adapt Cont Signal Process. 22:180- 197.

Wisemans, Z., Epstein, E. 1987. Metabolism and transport of 5- Hindole- 3- butyric acid in cuttings of olive. Olea. 18:29- 33.

\section{How to cite this article:}

Adriatik Çakalli, Hairi Ismaili, Endrit Kullaj and Ervin Shishmani. 2018. Rhizogenesis Analysis of Some Olive Accessions. Int.J.Curr.Microbiol.App.Sci. 7(10): 2919-2924. doi: https://doi.org/10.20546/ijcmas.2018.710.339 